\title{
ПОЛИНА ИВАНОВА \\ СЕЗОННЫЕ МИГРАЦИИ НА ДАЧУ КАК ОДНА ИЗ ПРАКТИК ФОРМИРОВАНИЯ УРБАНИСТИЧЕСКОГО ДЕТСТВА У МОСКВИЧЕЙ
}

Иванова Полина Евгеньевна, магистрантка 2-го года обучения образовательной программы «Управление пространственным развитием городов» Высшей школы урбанистики имени А.А. Высоковского ФГРР НИУ ВШЭ; Российская Федерация, 101000, г. Москва, ул. Мясницкая, д. 13 стр. 4.

E-mail: polina.zero@yandex.ru

Распространенность сезонной временной миграции на дачи является одной из особенностей российской урбанизации. До 2/3 городского населения страны владеют дачами разных типов. Участниками поездок между городом и дачей помимо самих горожан становятся и их дети, которые таким образом получают новый опыт социализации и досуговых практик. В отличие от городского, дачному детству пока не свойственна регламентированность, институционализация и преобладание пассивных форм досуговых практик.

Цель данной статьи - реконструировать дачный опыт городского ребенка и оценить его значимость в детстве. На основе данных, полученных с помощью полуструктурированных интервью, были выявлены и описаны основные характеристики дачного детства и представления о даче как пространстве детства. В качестве респондентов были выбраны горожанеродители, которые регулярно совершают совместные поездки на дачу с детьми, при этом большую часть времени проживают в городе (в нашем случае это Москва). Выбор родителей как основных информантов объясняется тем, что они являются создателями дачного детства и оказывают большое влияние на формирование детского досуга.

Итогом статьи стало описание дачи как пространства, создающего уникальные детские практики, характеристиками которых являются преобладание природного компонента, большая роль семейной и межпоколенческой социализации, меньшая степень контроля со стороны родителей. Дачный опыт оказывается отличным от городского за счет возможности реализации различных практик, для которых нет времени или места в городе. Такими практиками оказываются игры на открытом воздухе, изучение природы, семейный досуг, различные виды рукоделия и ремесла, спортивные активности. Данные характеристики подтверждают гипотезу о создании на даче возможностей для получения нового опыта, который восполняет важные элементы детства, постепенно исчезающие в городе.

Ключевые слова: детство; городское детство; дачи; дачное детство; сезонная субурбанизация; сезонные миграции

Цитирование: Иванова П.Е. (2020) Сезонные миграции на дачу как одна из практик формирования урбанистического детства у москвичей//Городские исследования и практики. Т. 5. № 3. С. 66-77. DOI: https://doi.org/10.17323/ usp53202066-77

\section{Введение}

$\Pi$ о оценке Федеральной службы государственной статистики, на 1 января 2019 года в России городское население составляло $74 \%$ от общей численности ${ }^{1}$, и в дальнейшем доля городского населения продолжит расти. В процесс стремительной урбанизации вовлечены и дети, зависимые от решений и действий взрослых [Майорова-Щеглова, 2018]. Поэтому актуален вопрос адаптации городской среды для детей. Его решение обсуждалось в том числе на конференциях ООН по населенным пунктам, и результатом этого стала концепция города,

1 Витрина статистических данных: https://showdata.gks.ru/report/278932/. 
доброжелательного к детям¹. В таком городе детям обеспечивается возможность безопасных прогулок, жизни в незагрязненной среде, участия в культурных и общественных мероприятиях и т.п.

Одновременно с ускорением урбанизации есть тенденция субурбанизации - выезд из крупных городов в субурбию на постоянное место жительства. В России же большее распространение получила практика сезонной деконцентрации на дачи [Нефедова, 2018]; это связано с недостаточной развитостью внегородской инфраструктуры, исторической традицией и наличием городского жилья как личного капитала. Дополнительным фактором стало то, что в советское время дача не могла быть постоянным и легальным жильем из-за отсутствия института частной собственности, и она так и осталась загородным вторым домом, не став постоянным местом жительства, как это случилось на Западе. Сейчас до 2/3 городского населения страны владеют дачами разных типов [Махрова, 2015], что на порядок выше, чем в других странах. В Англии число вторых домов - порядка 650 тыс., а в США их доля составляет около 5\% [Трейвиш, 2014].

Российские дачи активно изучаются как зарубежными [Lovell, 2003], так и российскими исследователями. Это работы Т. Г. Нефедовой, в которых приводится классификация типов дачного жилья, исторические формы дач и современный характер их использования [Нефедова, 2011; 2012], исследования А. И. Трейвиша, в которых поднимаются вопросы дачной мобильности [Трейвиш, 2014; 2015] и дачного менталитета, то есть наличие у дачников таких ценностей, как рекреационно-экологические, инвестиционные, пенсионные, наследственно-ностальгические и трудовые [Трейвиш, 2013]. Кроме того, феномен российских дач рассматривается в ряде монографических исследований, посвященных возвратной пространственной мобильности в России [Нефедова, Аверкиева, Махрова, 2016] и сельско-городскому сообществу в целом [Ильин, Покровский, 2016]. Большинство исследователей сходятся во мнении, что дача, как временное сезонное и второе жилье, не уникальна для России, но достигла здесь наибольшего распространения.

Значительно меньше исследований посвящено агентам, которые участвуют в практике сезонной миграции. В большинстве случаев под агентами автоматически подразумевают взрослых людей, совершающих поездки на дачу по причине физиологической и психологической усталости от быстрого темпа города [Ильин, Покровский, 2016]. Дети же исследуются в контексте существования уникального дачного социального института [Полухина, 2014]. Однако в целом можно говорить о том, что дети, как участники поездок, оказываются выключены из наблюдения, хотя, выезжая за пределы города вместе с родителями и проводя время на дачах, они получают новый, альтернативный городскому опыт социализации и досуговых практик.

Городское детство характеризуется дефицитом времени, отводимого на общение родителей с детьми, что часто компенсируется интернет-общением, а преобладание нуклеарного характера семьи приводит к дефициту межпоколенческого общения [Верещагина, Бандурин, Самыгин, 2016]. Школа как институт тоже претерпевает изменения. Появляются новые формы обучения, на первый план выходит роль школы не как места, где возможна социализация ребенка, а как места обучения. Такое изменение привычных каналов социализации влияет на появление и распространение различных движений, субкультур среди сверстников. С другой стороны, школа и семья, стараясь сохранить прежний порядок, ужесточают меры контроля. Одной из форм контроля становится организация родителями досуга ребенка - кружки, секции, репетиторы [Поливанова, 2012].

В городских условиях преобладают пассивные формы досуговых практик, чаще всего это проведение свободного времени дома с компьютерами и телевизорами. Активные практики все меньше носят природный характер и больше - городской, например, походы в кинотеатр [Верещагина, Бандурин, Самыгин, 2016]. М.Ю. Сиберева в своем исследовании влияния мегаполиса на социализацию ребенка показала, что у детей формируется представление о городе как о каменном мешке [Сиберева, 2010].

Условия городской жизни оказывают влияние и на формы детского уличного досуга. Так, согласно А.А. Бочавер, А.Н. Корзун и К.Н. Поливановой, современных детей меньше допускают к уличному пространству и сильнее контролируют. В городе появляются и унифицируются специализированные детские пространства [Бочавер, Корзун, Поливанова, 2017]. Количе-

1 Подробнее об инициативе Child Friendly Cities: http://childfriendlycities.org. 
ство детской активности на улице сокращается, уменьшается и свобода детских перемещений [Hillman, Adams, Whitelegg, 1991]. При этом у детей, в особенности подростков, значительно расширяются возможности посещения различных культурных и общественных мест в городе.

В научной литературе о детстве внегородской образ жизни рассматривается значительно реже, чем городской, и скорее понимается как конструируемые и разделяемые родителями представления о детстве. В частности, в контексте экологических проблем города [Там же]. Так, в статье [Покровский, Николаева, Демидова, 2019] приводятся следующие слова москвички: «Когда мы смогли - мы тоже дом в деревне купили. Детям было очень полезно находиться здесь для здоровья». В зарубежных исследованиях тоже подчеркиваются экологические потребности детей, которые усиливаются в связи с процессами урбанизации [Hugh, Limb, 1999].

Тема дачного опыта в детстве чрезвычайно актуальна. Учитывая масштабы сезонной миграции, в особенности в Московском регионе, для многих дачный опыт является одной из составных частей городского детства. По некоторым оценкам, в будущем процессы временной миграции будут только увеличиваться [Булатова, 2020], к тому же в условиях пандемии и самоизоляции наблюдается спрос на покупку дач и загородных домов ${ }^{1}$.

Моя цель - реконструировать дачный опыт городского ребенка путем изучения представлений родителей о дачном детстве и оценить его значимость для развития ребенка. Исследовательский вопрос, на который я ищу ответ, - как совместные поездки родителей и детей на дачу становятся частью городского детства.

Изучение поездок на дачу как способа создания «платформы» для воспитания требует синтеза исследований городского детства и дачного образа жизни. Так, опираясь на анализ исследований городского детства, я изучу досуговые практики ребенка (чем дети занимаются в свободное время и где проходят эти занятия), а также процесс социализации и ее каналы (семья, друзья, общественные институты социализации). Анализ исследований, посвященных тематике второго дома, показал, что при изучении поездок на дачу важна мотивация их совершения.

Соответственно будут решаться следующие задачи:

- описать, как представления о даче как пространстве детства влияют на мотивацию родителей совершать регулярные поездки во второе жилье с детьми;

- описать дачный детский опыт и какие его компоненты являются важными для городского ребенка с точки зрения родителей.

Методологически данное исследование опирается на полуструктурированные интервью средней продолжительностью один час. Всего было взято 12 неформализованных интервью. Вопросы интервью направлены на понимание причин и факторов, влияющих на решение жителей города отправить ребенка на дачу, раскрытие воспоминаний о детстве их детей и характере их занятий на даче - типичный день ребенка, любимые активности. На выявление отличий дачи от города направлены вопросы о том, как досуговые практики и практики социализации реализуются в условиях города.

В роли основных информантов выбраны горожане-родители, которые регулярно отвозят своих детей на дачу на выходные или на все лето. При этом большую часть времени семья проживает в городе (в нашем случае - в Москве), то есть дача является сезонным жильем. Выбор родителей в качестве информантов обусловлен тем, что, во-первых, родители являются создателями дачного детства, поскольку дети ездят на дачу совместно с родителями. Во-вторых, в условиях современной городской жизни контроль за детьми усиливается - особенно со стороны родителей, которые жестко регламентируют перемещения и определяют досуг ребенка [Бочавер, Корзун, Поливанова, 2017], - и дачное пространство оказывается для детей противоположным опытом, так как здесь степень их самостоятельности обычно гораздо выше, а родительский контроль - ниже и осуществляется иначе. Типичный респондент - человек в возрасте от 25 до 55 лет, со средним достатком, владеет дачным участком и проживает в Москве. Выбор нижней границы обусловлен тем, что в Москве возраст 25-29 лет является средним возрастом рождения первого ребенка [Архангельский, Зверева, Поливанова, 2011].

Вопросы интервью были сформулированы так, чтобы понять, что мотивирует родителей приобщать ребенка к даче, чем жизнь ребенка на даче отличается от городской, в чем различие дачи и города, когда мы говорим о детстве, а также чтобы вызвать воспоминания родителей о детстве их детей, характере их занятий на даче и выявить, является ли в восприятии роди-

1 ТАСС//Эл. ресурс. Режим доступа: https://tass.ru/nedvizhimost/8448061 (дата обращения: 18.05.2020). 
телей дача пространством детства. В интервью с респондентами начало периода взросления понималось как наступление самостоятельности, то есть момент окончания совместных поездок ребенка и родителей на дачу. В соответствии с ответами респондентов это возраст от 12 до 18 лет.

Типичное дачное пространство, анализируемое в статье, можно рассматривать как ближнюю дачу в пределах 250 км от Москвы, советского садоводческого типа, размером 6-9 соток, с личным участком, на котором присутствует природный компонент - деревья, цветы, грядки - и который огражден забором. Дача также является частью садоводческого-некоммерческого товарищества.

Основываясь на результатах эмпирического исследования, я реконструирую образ дачного детства в представлениях родителей через изучение мотивов поездок на дачу, описание досуга и процессов социализации ребенка на даче и в городе.

\section{Образ дачи и мотивы поездок на дачи}

Есть разные мотивы перехода к дачному образу жизни. В.И. Ильин в результате изучения отдаленных дач в Костромской области выделяет следующие: поиск временного альтернативного мира из-за усталости от городского образа жизни, стремление к изменению модели социализации и выталкивание из города из-за разных аспектов городского образа жизни (быстрый темп жизни, экология) [Ильин, 2016]. Одной из причин также является желание родителей познакомить ребенка с пространством дачи, которое контрастно отличается от городского. Дача как пространство детства представляется родителям более привлекательным, чем город, хоть и совершенно невозможным без него, о чем я буду говорить в дальнейшем.

Город воспринимается как «неинтересное» и «скучное» пространство. На даче у детей появляется возможность познакомиться с окружающим миром в естественных условиях и приобрести бытовые навыки эмпирическим путем - познавая через движение и тело, используя сенсомоторный интеллект.

...детям там гораздо более интересней и лучше, нежели в городе. Для них это смена обстановки, и они там более расслабленные. И для них это такое времяпрепровождение, когда им больше позволяется. Можно ковыряться в грязи, можно копать, лепить, ходить по лужам, строить шалаши, такое развитие детской фантазии, но не в городских условиях, не когда ты сидишь дома, лепишь или с горки катаешься. А именно когда природное (Т., 49 лет).

С точки зрения родителей, город предоставляет ограниченный круг активностей для детей. Большинство респондентов перечисляли одни и те же детские практики, в основном связанные с пространством детских площадок, - катание на качелях, игры в песочнице и другие. Это подтверждается исследованиями снижения детской активности в городе и сокращения пространств детских перемещений [Hillman, Adams, Whitelegg, 1991]. Детское городское пространство оказывается регламентированным и упорядоченным. В дачном пространстве нет правил и предписаний из-за наличия собственной, приватной земли, а за пределами участка уровень регламентации ниже, чем в городе. Это своеобразная дачная свобода, описываемая информантами как свобода перемещений на собственном участке, где ничто и никто не может тебя ограничить. Некоторые респонденты также отмечали, что на даче свободней, потому что, чтобы оказаться на улице, нужно просто выйти из дома. Нет необходимости долго одеваться и собираться. Эта простота и отсутствие формальных обязательств, касающихся внешнего вида, дарят чувство свободы. Дачная свобода - это также свобода доступа к окружающему миру, возможность беспрепятственного взаимодействия с ним.

Это ощущение пространства, бесконечности пространства. Когда смотришь и видишь линию горизонта, не закрытую домами. Когда видишь бесконечный лес, поля борщевика, полет аиста. Bот это ощущение пространства (А., 50).

На даче бытовая свобода. В квартире, чтобы выйти, нужна цель (O., 25).

Ассоциации с «чувством семьи и передачей семейных традиций» (Е., 49) придают даче важность. У ребенка появляется возможность провести время с родственниками, бабушками, 
дедушками. Получается, что город - это преимущественно пространство нуклеарной семьи, а дача - расширенной семьи, где одновременно могут находиться несколько поколений. У одних респондентов долговременное взаимодействие ребенка с родственниками могло происходить только на даче. У других ребенок и в городе общался с родственниками, однако совместные занятия были возможны только на даче в связи с тем, что в городе у ребенка и взрослых значительно меньше свободного времени.

Опираясь на образ дачи как пространства детства, можно выделить пять основных мотивов, по которым родители берут своих детей на дачу. Во-первых, на даче дети могут познакомиться с окружающим миром как в пределах дачного участка, так и за его пределами, во-вторых - приобрести бытовые навыки. В-третьих, дача воспринимается как пространство семьи, где ребенок может провести время с родственниками. Четвертая причина связана с переносом собственных представлений и воспоминаний родителя о дачном детстве на детей и стремлением подарить ребенку похожий опыт. Пятая причина - забота об экологически чистой и безопасной среде, городское лето - нередко душное, пыльное и грязное, совершенно неподходящее для детства. Все это делает дачу привлекательным местом для родителей и мотивирует совершать туда регулярные поездки с участием детей.

\section{Детские дачные практики}

Образ жизни на даче отличается от городского, что проявляется в различных уникальных практиках, возможных только на даче. На основе результатов эмпирического исследования я выделила следующие категории практик.

Первая категория - детский досуг на природе. Это и совместное времяпровождение взрослых с детьми (походы в лес за грибами или ягодами, прогулки на речку, на поле), и самостоятельное знакомство ребенка с природой на дачном участке (ловля жуков и бабочек, копание в грязи, наблюдение за растениями). У ребенка появляется возможность самостоятельно изучать природу, так как родители воспринимают дачное пространство участка как безопасное и ослабляют контроль.

На даче можно походить босиком, чего не сделаешь в городе, опасаясь осколков (А., 50).

Вчера они [дети] меня просто звали в лес пойти. Они мне говорят: посмотри, вот тут деревья, вот такие птицы. Уних неподдельный интерес к природе и ко всему, что вокруг (T., 37).

Почему родители считают дачу более безопасной? В первую очередь потому, что в дачных поселках меньше автомобилей. Вторая причина - знакомство с соседями и ощущение того, что вокруг все свои. Один из респондентов объяснил это тем, что на дачу едут «целенаправленно» (O., 25), то есть только дачники. На даче также снижается уровень общей тревожности. Большинство респондентов говорят о чувстве расслабленности на даче, ощущении спокойствия, в то время как город связан со стрессом.

На даче существуют ограничения, свойственные современному детству [Бочавер, Корзун, Поливанова, 2017]. Так, некоторые респонденты, вспоминая собственное детство, отмечали, что им позволялось больше и следили за ними меньше. «Я больще себя в детстве помню, что мы могли уехать очень далеко на велосипедах, поэтому я сразу же понимаю, куда можно уехать. Поэтому никуда не отпускаю» (T., 37). Однако дача считается более безопасным пространством для ребенка. Это касается и территории участка за счет ее приватности, и территории дачного поселка за счет факторов, перечисленных выше.

Вторая категория детских практик на даче - совместное семейное времяпрепровождение. Это могут быть как самостоятельные активности детей на участке и за его пределами, о которых говорилось выше, так и совместный досуг. Ярким примером являются настольные игры, в которые дети играют с родителями: «Имаджинариум», «Монополия» и другие. У многих семей это занятие становится исключительно дачным. «Мы прям открыли для себя настольные игры и вместе с детьми теперь играем на даче, а в городе не играем» (T., 37).

Родители также обучают и вовлекают детей в карты, шашки, шахматы. Это позволяет ребенку быть включенным в занятия взрослых, появляются традиции местных дачных вечеров. Для взрослых дача - это пространство, где можно заниматься различными хобби, на которые в городе не хватает времени и места, у детей тоже появляется возможность изучить новые для 
них сферы и получить новые навыки. «У нас был дедушка, у которого на даче были машины, и они [дедушка и ребенок] в машине ковырялись, мыли, ремонтировали ее» (E., 49).

Отдельную роль в семейных практиках играет приобщение ребенка к выполнению различных бытовых действий - уборке, готовке, в целом помощи по дому. Часто это начинается как совместные действия детей и взрослых и иногда становится некой дачной трудовой повинностью.

Все дети всегда участвовали в посадке огорода, в уборке овощей, в заготовках, с самого первого дня мы сажаем огород, посадили тут [на даче] яблони, ягодные кусты. Дети к семи годам уже все умели: и колоть дрова, и растопить печку. Теперь уже у нас есть баня и вот мальчик, которому 12 лет, мы вдвоем с ним живем сейчас, он отвечает за все. За то, чтобы дрова приносить в дом, чтобы они тут были. За то, чтобы топить баню, растапливать печь (Н., 47).

Мы стараемся ребенку объяснять, что все работают, - значит, и ты тоже должен работать сейчас. Все готовят, мясо жарят - значит, ты тоже должен. Бабушке они помогают. Все, что касается именно там огорода и посадок. Но ему нравится. Он с другом помогал красить дом и гараж, и они, как в книге про Тома Сойера, наперебой просили эту краску, чтобы покрасить гараж (T., 37).

С точки зрения родителей, дача - это место, где возможна самореализация ребенка. Например, к дачному интерьеру многие относятся проще, чем к городскому, иногда с большей фантазией и уровнем дозволенности, а сам дом становится самодельным пространством как для взрослых, так и для детей.

Дети на даче ставили спектакли. Им доставали мешок с тряпьем, старыми шторами и тюлями. Они сами шили себе костюмы, сами ставили спектакли. Дача была местом, где это возможно было сделать (Т., 49).

У нас тут [на даче] дети соседские, и Игорь, их дедушка, наш ровесник. Так он так извращается. Столько всего понаделал, сделал им горку, в виде дракона скульптуру. Поперла фантазия за счет детей (C., 49).

Что касается детской социализации в дачных условиях, то она в первую очередь проходит в кругу семьи. Дача часто становится местом, где нет спешки и у родителей появляется больше свободного времени, которое можно провести вместе с ребенком. «Рома все лето проводил с бабушкой, дедушкой. Много общался с ними. Дедушка его шахматам научил, самолеты с ним собирал» (E., 49). За счет того, что на даче возможно совместное проживание нескольких поколений и разных родственников, у ребенка появляется возможность межпоколенческой социализации. Отсутствие ее при нуклеарном характере городской семьи может быть одной из причин появления разрывов в историческом сознании, как процессе передачи знаний о семье, об истории из поколения в поколение [Верещагина, Бандурин, Самыгин, 2016]. На даче уменьшается влияние интернета как канала социализации, потому что, с одной стороны, многие родители здесь сильнее ограничивают использование гаджетов, а с другой - не на всех дачах выход в интернет в принципе возможен.

\section{Выводы}

Поездки на дачу как процесс сезонной миграции из города являются одной из практик досуга, доступной и возможной для многих жителей города. Родители-горожане, вовлекая в поездки своих детей, создают дачное детство, которое для этих детей становится частью городского детства.

Важная черта такого образа жизни - его двойственность и полярность, заключенная в контрасте города и дачи. Следуя концепции М. Бахтина о двойном восприятии мира и человеческой жизни [Бахтин, 1990], город и дача не могут существовать друг без друга. Поэтому большинство респондентов не представляют окончательного переезда на дачу и отказа от благ города. При этом собираются продолжать поездки на дачу, чтобы «чвствовать контраст между городскими джунглями и чистой природой» (С., 49). 
Дачный опыт в детстве дает ребенку то, что он не может получить в городе, и наоборот. Город постепенно становится институционализированным пространством, где дети по расписанию ходят в школу, кружки, секции. Дачное детство, по словам респондентов, свободное, более безопасное, чем в городе, и более разнообразное. Дача дает возможность реализовывать различные практики, невозможные в городских условиях из-за нехватки на них времени или неподходящих условий. Один из респондентов поделился словами ребенка: «Мама, у меня в городе нет детства, хочу на дачу» (T., 39).

Дачное пространство в целом описывается как организованное вокруг взрослых, поскольку взрослые занимаются собственными делами, а ребенок встраивается в этот процесс и участвует в нем. Исключая, конечно, период, когда ребенок еще маленького возраста и не может передвигаться самостоятельно. В городе меньше свободы в выборе занятий. Так, по словам респондентов, если на даче ребенок помогает бабушке в посадке растений, уборке и имеется возможность иного разнообразного совместного досуга, то в городе их взаимодействие в большинстве случаев - помощь бабушки ребенку с уроками.

Контрастные поездки из города на дачу и обратно делают детство менее однородным, придают ему фактурность, дарят, по мнению родителей, новый опыт. Поездками на дачу родители расширяют детские территориальные границы и помогают в освоении и осмыслении мира. Меньше ограничивая детей и давая им свободный доступ к пространству, к различным предметам, родители благоприятно влияют на формирование у детей собственного «Я» [Осорина, 2019]. В связи с усилением контроля родителей за жизнью ребенка в городе, в том числе за его досугом, дача позволяет ребенку свободно реализовать многие свои желания, особенно в доподростковом возрасте, когда на первом плане стоит скорее познание мира, а не социализация.

Дача действительно формирует уникальные детские практики, становится частью дачного детства [Полухина, 2014]. Одна из его характеристик - преобладание природных досуговых практик, доступ к которым в городе почти отсутствует. Так, исследования 1990-х годов показывают, что для игры и свободного времяпрепровождения дети предпочитают природные среды [Бочавер, Корзун, Поливанова, 2017], а исследования 2010-х годов говорят о том, что у городских детей уменьшается доступ к природе и в городе появляются специализированные детские места [Gastonguay, 2009]. Поэтому дача становится пространством, в котором возможно осуществление природных практик и долговременный контакт с природой. Это дает возможность ребенку расширить образ детства [Осорина, 2019].

Другие характеристики дачного детства - большая, чем в городе, роль социализации в кругу семьи, при этом зачастую расширенной, обучение бытовым навыкам, включение ребенка в занятия взрослых, бо́льшая возможность самостоятельного времяпрепровождения и познания окружающего мира. Все это способствует созданию нового опыта для городских детей, важность которого подчеркивается респондентами.

Родители, совершая поездки на дачу с детьми, восполняют тем самым важные элементы детства, роль которых постепенно уменьшается в городе. Так, современное детство в городе характеризуется отсутствием самостоятельной мобильности, снижением свободного передвижения пешком и уменьшением активностей на свежем воздухе, что влияет на развитие и благополучие детей [Prezza, Alparone, Cristallo, 2005]. Недостаток всего этого можно восполнить с помощью дачи.

Респонденты воспринимают город как необходимость. Он ассоциируется с социальными институтами работы, образования, культуры, здравоохранения. Это место, которое делает жизнь «комфортной» (M., 39), но при этом вызывает стресс и усталость. Ассоциативный ряд, связанный с дачей, более романтичен. Это природа - полеты аистов, цветение тюльпанов, спокойствие и умиротворение. «Дача - это отдушина» (T., 37). Такая романтизация свойственна и самому образу детства, который реконструируется из интервью с родителями, - свобода, безопасность, отдых. Но это лишь одна из сторон детского дачного опыта, другая - детство глазами самих детей.

\section{Заключение}

На даче границы детского мира расширяются благодаря закрытости территории участка, в котором находится ребенок. Появляется свободный доступ к природе в рамках дачного участка, 
увеличиваются возможности и варианты досуга. Самостоятельная мобильность детей в пространстве дачного поселения также выше, чем в городе. Сохраняются ограничения физические - границы СНТ или поселка. Однако детям разрешается больше, что обусловлено меньшим уровнем беспокойства и тревоги родителей. В городе, по словам респондентов, больше страхов и выше их концентрация - незнакомые люди и места, автомобили, неблагоприятная экологическая обстановка.

Набор детских практик на даче увеличивается по сравнению с городом, однако он все равно кажется регламентированным и навязанным родителями. $\mathrm{O}$ «дачной трудовой повинности» сами респонденты, вспоминая свое детство, говорили как о чем-то обязательном и больше похожем на наказание, чем на досуг. На даче социализация ограничена кругом семьи из-за отсутствия там других детей.

Ограничением данного исследования является выбор родителей в качестве информантов, что исключает из концептуализации исследования детей как важных участников урбанистического детства. Следствием этого также стала некоторая романтичность образа детства, поскольку дети не всегда рассказывают родителям о своих приключениях, и это не позволяет описать дачу как пространство риска, хотя она таковым является.

Таким образом, перспективное изучение образа дачного детства возможно и со стороны других акторов - детей, что позволит расширить образ дачного детства, дополнив его новыми характеристиками, и выявить различия между восприятием дачи детьми и родителями.

\section{Источники}

Архангельский В., Зверева Н. (2011) Рождаемость в Москве в 2000-е годы//Демоскоп Weekly. Режим доступа: http://www.demoscope.ru/weekly/2011/0489/tema05.php (дата обращения 23.04.2020).

Арьес Ф. (1999) Ребенок и семейная жизнь при старом порядке. Екатеринбург: Изд-во Уральского университета.

Бахтин М.М. (1990) Творчество Франсуа Рабле и народная культура Средневековья и Ренессанса. М.: Художественная литература.

Бочавер А.А., Корзун А.Н., Поливанова К.Н. (2017) Уличный досуг детей и подростков//Политология. Журнал Высшей школы экономики. Т. 14. № 3. С. 470-490.

Бреславский А.С. (2016) Какой может быть российская субурбанизация?//Мир России. Социология. Этнология. №1. С. 79-102.

Бреславский А.С. (2017) Что мы знаем о современных российских пригородах? Улан-Удэ: Изд-во БНЦ СО РАН.

Булатова А. (2008) Денис Визгалов: «Дачи - это массовая субурбанизация по-русски»//Экспертный портал IQ НИУ «Высшая школа экономики». Режим доступа: https://iq.hse.ru/news/177680081.html (дата обращения: 05.01.2020).

Верещагина А.В., Бандурин А.П., Самыгин С.И. (2016) Детство в условиях городской среды: риски социализации //Гуманитарные, социально-экономические и общественные науки. № 4.

Григоричев К.В. (2013) В тени большого города. Социальное пространство пригорода. Иркутск: Оттиск.

Григоричев К.В. (2016) Многообразие пригорода: субурбанизация в Сибирском регионе (случай Иркутска)//Городские исследования и практики. Т. 1. № 2. С. 7-20.

Ильин В.И., Покровский Н.Е. (2016) Горожане в деревне. Социологическое исследование в российской глубинке: Дезурбанизация и сельско-городские сообщества: коллективная монография. М.: Университетская книга.

Кон И.С. (1988) Ребенок и общество. М.: Просвещение.

Кон И.С. (2004) Детство как социальный феномен//Журнал исследований социальной политики. Т. 2 . № 2. С. $151-174$.

Майорова-Щеглова С.Н. (2014) Трансформации детства в начале XXI в. К уточнению концепции социального конструирования детства//Вестник РГГУ. Серия «Философия. Социология. Искусствоведение». № 4 (126). С. $173-183$

Майорова-Щеглова С.Н. (ред.) (2018) Детство XXI века: социогуманитарный тезаурус. М.: Изд-во РОС.

Махрова А.Г. (2015) Сезонная субурбанизация в регионах России //Вестник Московского университета. Серия 5. География. № 4. С. 59-67.

Нефедова Т.Г. (2001) Российские пригороды. Горожане в сельской местности//Город и деревня в Европейской России: сто лет перемен. М.: ОГИ. С. 374-399.

Нефедова Т.Г. (2011) Российские дачи как социальный феномен//SPERO. Осень-зима 2011. № 15. C. 161 -172. Режим доступа: http://www.intelros.ru/intelros/reiting/reyting_09/material_sofiy/17838-rossiyskie-dachi-kaksocialnyy-fenomen.html (дата обращения: 22.04.2020). 
Нефедова Т.Г. (2012) Горожане и дачи//Отечественные записки. № 3. С. 204-216.

Нефедова Т.Г. (2013) Десять актуальных вопросов о сельской России: Ответы географа. М.: ЛЕНАНД.

Нефедова Т.Г., Аверкиева К.В., Махрова А.Г. (2016) Между домом и... домом. Возвратная пространственная мобильность России. М.: Новый хронограф.

Нефедова Т.Г., Покровский Н.Е., Трейвиш А.И. (2015) Урбанизация; дезурбанизация и сельско-городские сообщества в условиях роста горизонтальной мобильности //Социологические исследования. № 12. С. 60-69.

Нефедова Т.Г., Савчук И.Г. (2014) Второе загородное жилье горожан в России и Украине: эволюция дач и тренды их современных изменений//Известия РАН. Серия «География». № 4. С. 39-47.

Нефедова Т.Г.; Трейвиш А.И. (2012) Между городом и деревней//Мир России. № 4. С. 61-82.

Осорина М.В. (2019) Секретный мир детей в пространстве мира взрослых. СПб.: Питер.

Покровский Н.Е, Николаева У.Г., Демидова Ю.А. (2019) Феноменология «жизненного мира» горожанина во внегородском пространстве Ближнего Севера: дом и доместикация//Социологические исследования. № 12. С. $71-80$.

Поливанова К.Н. (2012) Практики развития: взросление в современном мире//Материалы научно-экспертного семинара «Новое детство». Режим доступа: https://psyjournals.ru/newchildhood/issue/56292.shtml (дата обращения: 17.04.2020).

Полухина Е.В. (2014) Особенности социального порядка в постсоветском пространстве: труд; поколение и гендер//Лабиринт. Журнал социально-гуманитарных исследований. № 3. С. 71-80.

Сиберева М.Ю. (2010) Влияние мегаполиса на социализацию ребенка//Социологические исследования. № 7. С. 147-150.

Трейвиш А.И., Нефедова Т.Г. (2013) Урбанизация; контрурбанизация; пространственная мобильность населения и роль дачников на Ближнем Севере//Дезурбанизация и природный капитал: миграционные тренды; инфокоммуникация и новые сельские сообщества: Материалы IV Международной научной конференции; Костромская область; деревня Медведево; 9-11 мая 2013 г./под ред. Н.Е. Покровского, Т.Е. Нефедовой (ред.). М. С. 57-76.

Трейвиш А.И. (2014) «Дачеведение» как наука о втором доме на западе и в России//Известия РАН. Серия «География». № 4. С. $22-32$.

Трейвиш А.И. (2015) Дачная мобильность; дачный менталитет и дачеведение//Демоскоп Weekly. № 655-656. Peжим доступа: http://www.demoscope.ru/weekly/2015/0655/demoscope655.pdf (дата обращения: 22.04.2020).

Gastonguay G., Jutras S. (2009) Children's Appreciation of Outdoor Places in a Poor Neighborhood//Journal of Environmental Psychology. Vol. 29 (1). P. 101-109.

Harris R. (2010) Meaningful Types in a World of Suburbs//Research in the Urban Sociology: Suburbanization in Global Society. Vol. 10. P. 15-47.

Hillman M., Adams J., Whitelegg J. (1991) One False Move: A Study of Children's Independent Mobility. London: PSI Publishing.

Hugh M., Limb M. (1999) Defining an Agenda for the Geography of Children: Review and Prospect//Progress in Human Geography. Vol. 23. No. 1. P. 61-90.

Lovell S. (2003) Summerfolk: A History of the Dacha; 1710-2000. London: Cornell University Press.

Prezza M., Alparone F.R., Cristallo C., Luigi S. (2005) Parental Perception of Social Risk and of Positive Potentiality of Outdoor Autonomy for Children: The Development of Two Instruments//Journal of Environmental Psychology. Vol. 25. No. 4. P. 437-453.

\section{Приложение}

Информант 1: Татьяна, 37 лет, один ребенок в возрасте 10 лет. Информант 2: Елена, 49 лет, один ребенок в возрасте 22 года. Информант 3: Тина, 49 лет, двое детей в возрасте 24 и 30 лет. Информант 4: Наталья, 47 лет, трое детей в возрасте 12, 19 и 26 лет. Информант 5: Олег, 25 лет, один ребенок в возрасте 2 года. Информант 6: Мария, 39 лет, один ребенок в возрасте 6 лет. Информант 7: Ксения, 36 лет, один ребенок в возрасте 7 лет. Информант 8: Александр, 50 лет, один ребенок в возрасте 23 года. Информант 9: Светлана, 49 лет, один ребенок в возрасте 7 лет. Информант 10: Анна, 27 лет, один ребенок в возрасте 5 лет. Информант 11: Евгения, 29 лет, двое детей в возрасте 1 и 4 года. Информант 12: Степан, 30 лет, один ребенок в возрасте 5 лет. 


\section{POLINA IVANOVA}

\section{SEASONAL MIGRATION TO \\ THE DACHA AS A PRACTICE OF \\ MOSCOVITE URBAN CHILDHOOD}

Polina E. Ivanova, Master's Student, Master's Program in Urban Development and Spatial Planning, Vysokovsky Graduate School of Urbanism, Faculty of Urban and Regional Development, HSE University; 13 bldg. 4 Myasnitskaya Street, Moscow, 10100, Russian Federation.

E-mail:polina.zero@yandex.ru

\section{Abstract}

The prevalence of temporary seasonal migration to the dacha is one of the key features of Russian urbanization. Up to two thirds of the Russian urban population own dachas of various types. Children are also participants in regular trips between the city and the dacha, getting new experiences of socialization and leisure. Unlike urban childhood, dacha childhood is not yet characterized by regulation, institutionalization or the predominance of passive forms of leisure.

This article reconstructs the image of the dacha experience of urban children and assess its significance for childhood. Based on data obtained through semi-structured interviews, the main characteristics of dacha childhood and the vision of the dacha as a childhood space are identified and described. The respondents regularly make trips to the dacha with their children, while most of the time they live in the city, in our case Moscow. The choice of parents as the main informants is explained by the fact that they are the creators of the dacha childhood and have a great influence on the formation of children's leisure time.

The results describe the dacha as a space that creates unique children's practices, the characteristics of which are the predominance of the natural environment, the greater role of family and intergenerational socialization, and a lesser degree of parental control. The dacha experience is different from the urban one due to the possibility for activities for which there is no time or place in the urban space. Such practices include outdoor games, nature study, family leisure time, handicrafts, and sports. These characteristics confirm the hypothesis about the creation of opportunities for new experiences in the countryside, which are important elements of childhood and which are gradually being lost in the city.

Keywords: childhood; urban childhood; dacha; dacha childhood; seasonal suburbanization; seasonal migration Citation: Ivanova P. (2020) Seasonal Migration to the Dacha as a Practice of Moscovite Urban Childhood. Urban Studies and Practices, vol. 5, no 3, pp. 66-77. (in Russian) DOI: https://doi.org/10.17323/usp53202066-77

\section{References}

Arhangel'skij V.,Zvereva N. (2011) Rozhdaemost'v Moskve v 2000-e gody [Birth Rate in Moscow in the 2000s]. Demoskop Weekly.Available at: http:www.demoscope.ru/weekly/2011/0489/tema05.php (accessed 23 April 2020). (in Russian)

Ar'es F. (1999) Rebenok i semejnaya zhizn' pri Starom poryadke [Child and Family Life Under the Old Order] Ekaterinburg: Izd-vo Ural'skogo universiteta. [Ural University Press] (in Russian)

Bahtin M.M. (1990) Tvorchestvo Fransua Rable i narodnaya kul'tura srednevekov'ya i Renessansa [Rable and His World]. M.: Hudozhestvennaya literatura [Mocow: Fiction Literature]. (in Russian)

Bochaver A.A., Korzun A.N., Polivanova K.N. (2017) Ulichnyj dosug detej i podrostkov [Street Leisure of Children and Adolescents]. Politologiya. Zhurnal Vysshej Shkoly Ekonomiki [Politology. Journal of the Higher School of Economics] V.14. no 3 pp. 470-490. (in Russian)

Breslavskij A.S. (2016) Kakoj mozhet byt' rossijskaya suburbanizaciya? [What Could Be the Russian Suburbanization?]. Mir Rossii. Sociologiya. Etnologiya [The World of Russia. Sociology. Ethnology], no 1, pp.79-102. (in Russian)

Breslavskij A.S. (2017) Chto my znaem o sovremennyh rossijskih prigorodah? [What Do We Know about Modern Russian Suburbs?] Ulan-Ude. BNC SO RAN. (in Russian)

Bulatova A. (2008) Denis Vizgalov: "Dachi - eto massovaya suburbanizaciya po-russki” [Denis Vizgalov: The Dachi is Massive Suburbanization in Russia]. Ekspertnyj portal IQ NIU “Vysshaya shkola ekonomiki” [Expert Portal IQ Higher school of Economics]. Available at: https:.iq.hse.ru/news/177680081.html (accessed 05 January 2020). (in Russian) 
Il'in V.I., N.E. Pokrovskij (2016) Gorozhane v derevne. Sociologicheskoe issledovanie v rossijskoj glubinke: Dezurbanizaciya i sel'sko-gorodskie soobshchestva: kollektivnaya monografiya [Sociological Research in the Russian Outback: Deurbanization and Rural-Urban Communities: Collective Monograph]. Moska: Universitetskaya kniga [Moscow: University book]. (in Russian)

Gastonguay G., Jutras S. (2009) Children's appreciation of outdoor places in a poor neighborhood. Journal of Environmental Psychology, vol. 29 (1), pp. 101-109.

Grigorichev K.V. (2013) V teni bol'shogo goroda. Social'noe prostranstvo prigoroda [In the Shadow of a Big City. The Social Space of The Suburb]. Irkutsk: Ottisk. (in Russian)

Grigorichev K.V. (2016) Mnogoobrazie prigoroda: suburbanizaciya v sibirskom regione (sluchaj Irkutska) [Suburban Diversity: Suburbanization in the Siberian Region (the Case of Irkutsk)]. Gorodskie issledovaniya i praktiki [Urban Studies and Practices], vol. 1, no 2, pp. 7-20. (in Russian)

Harris R. (2010) Meaningful Types in a World of Suburbs. Research in the Urban Sociology: Suburbanization in Global Society, vol. 10, pp. 15-47.

Hillman, M., Adams J., Whitelegg J. (1991) One false move: A study of children's independent mobility. London: PSI Publishing.

Hugh M., Limb M. (1999) Defining an agenda for the geography of children: review and prospect. Progress in Human Geography, vol. 23, no 1, pp. 61-90.

Kon I.S. (2004) Detstvo kak social'nyj fenomen [Childhood as a Social Phenomenon]. Zhurnal issledovanij social'noj politiki [Journal of Social Policy Studies], vol. 2, no 2, pp. 151-174. (in Russian)

Kon I.S. (1988) Rebenok i obshchestvo [Children and Society]. M.: Prosveshchenie [Moscow: Enlightenment]. (in Russian)

Lovell S. (2003) Summerfolk: A History of the Dacha, 1710-2000. London: Cornell University Press.

Mahrova A.G. (2015) Sezonnaya suburbanizaciya v regionah Rossii [Seasonal Suburbanization in Russian Regions]. Vestnik Moskovskogo universiteta. Seriya 5. Geografiya [Herald of Moscow University. Series 5. Geography], no 4. pp. 59-67. (in Russian)

Majorova-Shcheglova S.N. (2014) Transformacii detstva v nachale XXI v. K utochneniyu koncepcii social'nogo konstruirovaniya detstva [Transformations of Childhood at the Beginning of the XXI Century. On Clarification of the Concept of Social Construction of Childhood]. Vestnik RGGU. Seriya «Filosofiya. Sociologiya. Iskusstvovedenie» [RSUH/RGGU Bulletin. Series Philosophy. Sociology. Art history], vol. 4 (126), pp. 173-183. (in Russian)

Majorova-Shcheglova S.N. (ed.) (2018) Detstvo XXI veka: sociogumanitarnyj tezaurus [Childhood of the XXI Century: Socio-Humanitarian Thesaurus]. M: ROS [Moscow: ROS]. (in Russian)

Nefedova T.G. (2001) Rossijskie prigorody. Gorozhane v sel'skoj mestnosti [Russian Suburbs. Citizens in the Countryside]. Gorod i derevnya v Evropejskoj Rossii: sto let peremen [City and Countryside in European Russia: A Hundred Years of Change]. M.: OGI, pp. 374-399. (in Russian)

Nefedova T.G. (2011) Rossijskie dachi kak social'nyj fenomen [Russian Dachas as a Social Phenomenon]. SPERO. Osen' - zima 2011 [SPERO], no 15, pp. 161-172. Available at: http:.www.intelros.ru/intelros/reiting/reyting_09/ material_sofiy/17838-rossiyskie-dachi-kak-socialnyy-fenomen.html (accessed 22 April 2020). (in Russian)

Nefedova T.G. (2012) Gorozhane i dachi [Citizens and Dachi]. Otechestvennye zapiski [Annals of the Fatherland], no 3, pp. 204-216. (in Russian)

Nefedova T.G. (2013) Desyat' aktual'nyh voprosov o sel'skoj Rossii: Otvety geografa [Ten Topical Questions about Rural Russia: Geographer's Answers]. Moscow: LENAND. (in Russian)

Nefedova T.G., Averkieva K.V., Mahrova A.G (2016) Mezhdu domom i... domom. Vozvratnaya prostranstvennaya mobil'nost' Rossii [Between Home and... Home. Reversible Spatial Mobility of Russia]. M.: Novyj hronograf [Moscow: New Chronograph]. (in Russian)

Nefedova T.G., Pokrovskij N.E., Trejvish A.I. (2015) Urbanizaciya, dezurbanizaciya i sel'sko-gorodskie soobshchestva v usloviyah rosta gorizontal'noj mobil'nosti [Urbanization, Deurbanization And Rural-Urban Communities in the Context of Growing Horizontal Mobility]. Sociologicheskie issledovaniya [Sociological Studies], no 12, pp. 60-69. (in Russian)

Nefedova T.G., Savchuk I.G. (2014) Vtoroe zagorodnoe zhil'e gorozhan v Rossii i Ukraine: evolyuciya dach i trendy ih sovremennyh izmenenij [Second Suburban Housing of Townspeople in Russia and Ukraine: Evolution of Summer Cottages and Trends of Their Modern Changes]. Izvestiya RAN. Seriya «Geografiya» [Bulletin of Russian Academy of Sciences. Geography Series], no 4, pp. 39-47. (in Russian)

Nefedova T.G., Trejvish A.I. (2012) Mezhdu gorodom i derevnej [Between Town and Country]. Mir Rossii [World of Russia], no 4, pp. 61-82. (in Russian)

Osorina M.V. (2019) Sekretnyj mir detej v prostranstve mira vzroslyh [The Secret World of Children in the Space of the World of Adults]. St. Petersburg: Piter. (in Russian) 
Pokrovskij N.E, Nikolaeva U.G., Demidova YU.A. (2019) Fenomenologiya «zhiznennogo mira» gorozhanina vo vnegorodskom prostranstve blizhnego severa: dom i domestikaciya [Phenomenology of the "Life World" of a Citizen in the Extra-Urban Space of the Near North: Home and Domestication]. Sotsiologicheskie Issledovaniia [Sociological Studies], no 12, pp. 71-80. (in Russian)

Polivanova K.N. (2012) Praktiki razvitiya: vzroslenie v sovremennom mire [Development practices: growing up in the modern world]. Materialy nauchno-ekspertnogo seminara «Novoe detstvo» [Materials of the Scientific and Expert Seminar “New Childhood”]. Available at: https:psyjournals.ru/newchildhood/issue/56292.shtml (accessed 17 April 2020). (in Russian)

Poluhina E.V. (2014) Osobennosti social'nogo poryadka v postsovetskom prostranstve: trud, pokolenie i gender [Features of the Social Order in the Post-Soviet Space: Labor, Generation and Gender]. Labirint. Zhurnal sotsial'nogumanitarnykh issledovanii [Labyrinth: Journal of Social and Humanities Research], no 3, pp. 71-80. (in Russian)

Prezza M., Alparone F.R., Cristallo C., Luigi S. (2005) Parental Perception of Social Risk and of Positive Potentiality of Outdoor Autonomy for Children: The Development of Two Instruments. Journal of Environmental Psychology, vol. 25, no 4, pp. 437-453.

Sibereva M.Y. (2010) Vliyanie megapolisa na socializaciyu rebenka [The Influence of the Metropolis on the Socialization of the Child]. Sociologicheskie issledovaniya [Sociological Studies], no 7, pp. 147-150. (in Russian)

Trejvish A.I. (2014) «Dachevedenie» kak nauka o vtorom dome na zapade i v Rossii ["Dachevedenie" as a Science of the Second House in the West and in Russia]. Izvestiya RAN. Ceriya «Geografiya» [Bulletin of Russian Academy of Sciences. Geography Series], no 4, pp. 22-32. (in Russian)

Trejvish A.I. (2015) Dachnaya mobil'nost', dachnyj mentalitet i dachevedenie [Dacha Mobility, Dacha Mentality and Summer Residence]. Demoskop Weekly, no 655-656. Available at: http:.www.demoscope.ru/weekly/2015/0655/ demoscope655.pdf (accessed 22 April 2020). (in Russian)

Trejvish A.I., Nefedova T.G. (2013) Urbanizaciya, kontrurbanizaciya, prostranstvennaya mobil'nost' naseleniya i rol' dachnikov na Blizhnem Severe [Urbanization, Counter-Urbanization, Spatial Mobility of the Population and the Role of Summer Residents in the Middle North]. Dezurbanizaciya i prirodnyj kapital: migracionnye trendy, infokommunikaciya i novye sel'skie soobshchestva: Materialy IV Mezhdunarodnoj nauchnoj konferencii, Kostromskaya oblast', derevnya Medvedevo, 9-11 mai 2013 [De-urbanization and natural capital: migration trends, infocommunication and new rural communities: Materials of the IV International Scientific Conference, Kostroma Region, Medvedevo village, 9-11 may 2013], pp. 57-76. (in Russian)

Vereshchagina A.V.,Bandurin A.P.,Samygin S.I.(2016) Detstvo v usloviyah gorodskoj sredy: riski socializacii [Childhood in the urban environment: risks of socialization]. Gumanitarnye, sotsial'no-ekonomicheskie i obshchestvennye nauki [Humanities, Socio-Economic and Social Sciences], no 4. (in Russian) 